\title{
THE RELATIONSHIPS BETWEEN ADOLESCENTS' SOCIAL EMOTIONAL HEALTH AND EXPRESSION OF EMPATHY
}

\author{
Ala Petrulytè \\ Virginija Guogienè
}

\begin{abstract}
The school at present has been facing such challenges as non-decreasing extent of bullying, suicides and high level of adolescents' behavioural as well as emotional problems. This calls for more research on positive adolescent development, its strengths, emotional and social areas of health, which can be developed. The goal of the research: to investigate adolescent social emotional health and empathy and their relationships. The research methodologies: Social and Emotional Health Survey (Furlong et al., 2014; You et al., 2015) and Interpersonal Reactivity Index (Davis, 1980). The sample: adolescents of 12-18 years old. The research conclusions: positive correlation between dimensions of adolescents' social and emotional health and empathy were identified. The results of the conducted research are significant in the context of positive development of adolescents and contribute to development of school learners' social and emotional health at school.
\end{abstract}

\section{Keywords}

social and emotional health, empathy, adolescents

\section{Introduction}

Mental health is considered to be one of the more relevant aspects of adolescents' health. The definition of mental health was expanded by the Mental Health Foundation (cit. in Wells, Barlow, \& Stewart-Brown, 2003) and now it is explained as a combination of emotional wellbeing, social functioning and a big number of competences that can be developed and improved. Research studies on the positive development of adolescents especially emphasising their ability to cope with crisis of psychosocial development are 
of utmost importance. The adolescent's ability to deal with challenges of psychosocial development and to overcome developmental crises, to large extent, depends on his or her social and emotional health as well as on emotional and social competences. The conducted research targets at adolescents' emotional and social health as to a multi-dimensional construct, which embraces a combination of person's psychological strengths, i.e. his or her positive dispositions. This includes fundamental personal strengths: belief in self, belief in others, emotional competence, and engaged living (You et al., 2015). The main contexts of this concept of adolescent social and emotional health encompass family, school, peer group and identity under formation together with belief in self and self-respect as well as their interaction and synergy. The main advantages of this model are based on understanding the health of a child/an adolescent as a multi-dimensional and dynamic construct of emotional and social health. Validity is characteristic of methodologies of psychological research. Moreover, extended possibilities for carrying out research on trajectories of child/adolescent development in various educational and socio-cultural contexts can be identified. The model of social and emotional health has been successfully tested and now has been implemented with help of scientific research (Furlong et al., 2014). The completed research showed that the construct of emotional and social health and strengths are linked with high level of mental health, psychological resilience and well-being.

Scholarly literature exhaustively discusses adolescents' empathy in the context of their psychosocial functioning and successful communication (Hoffman, 2000; Reynolds \& Scott, 1999; Kradin, 2005; Carr \& Lutjemeier, 2005; Pukinskaite, 2006; Van Noorden et al., 2015; Strayer \& Roberts, 2004; Denham, 1998; Eisenberg, Fabes \& Spinrad, 2006; Hoffman, 2000). A reaction of an individual to the inner state of another person, its understanding and emotional response to experience of another individual is defined as empathy (Baron \& Richardson, 2001, 27-29; Wied, Goudena, \& Matthys, 2005). In this study empathy is viewed as a multi-dimensional construct including emotional and cognitive processes (Davis, 1980; Batson, 2009; Decety \& Cowell, 2014). The emotional aspect of empathy is understood as indirect experience of another person's emotions, putting oneself into another's place, responsiveness and concern (Mehrabian \& Epstein, 1972; Davis, 1983; Cohen \& Strayer, 1996; Hoffman, 2000), as a sensual response to other people's experiences. The cognitive element of empathy refers to intellectual and analytical ability to identify oneself with others, and to understand feelings of other people relying on simple associations (White, 1997). This component also includes more complex cognitive processes such as understanding of the perspective of thoughts, intentions and behaviour of another person (Cliffordson, 2002; Wied, Goudena, \& Matthys, 2005) and allows to understand the attitude of others, their internal experiences and emotional reactions to this process (Davis, 1983). Empathy also embraces ability to show (pass over) own feelings and understanding to others and it is one of the factors that promotes support to each other (Davis, 1983; Cliffordson, 2002; White, 1997). Expressiveness of adolescent's empathy acquires particular importance. The higher level of adolescents empathy provides for favourable conditions that enable adolescents to experience and 
express positive emotions, contributes to anger control and other negative feelings and is a signal of prosocial behaviour (Cohen \& Strayer, 1996; Pukinskaite \& Guogienè, 2010). Teaching empathy and introducing social competences to adolescents enable them to learn to control own anger (O’Neil, 1996; Suslavičius, 2000).

Emotional intelligence, as one more object in the context of the research topic, is often determined as non-cognitive abilities and skills, which help to successfully deal with external demands and pressure (Baron, 2000). According to Mayer and Forgas (2001), Murphy et al. (2004) and Petrides et al. (2006) emotional intelligence is linked to adolescents' mental health, predetermines better social functioning and minifies features of destructive behaviour. Emotional intelligence has impact on the level of adolescents' behavioural and emotional difficulties, academic achievements, quality of interpersonal relations and social competence (Qualter \& Gardner, 2007), partially contributes to success of his or her coping with emotional and behavioural problems emerging in adolescence (Ivcevic, Brackett, \& Mayer, 2007). The results of research conducted by Petrides et al. (2006) and Reiff et al. (2001) show that adolescents of lower emotional intelligence tend to more frequently demonstrate aggressive behaviour and lack self-confidence. Adolescents of higher emotional intelligence are less aggressive, feel sympathy, understand own feelings and those of other people better (Rubin, 1999; Ciarrochi, Chan, \& Bajgar, 2001; Furnham \& Petrides, 2003; Palmer, Donaldson, \& Stough, 2002). The research results presented by Newsome, Day and Catano (2000) revealed that adolescents with higher emotional intelligence are more cheerful and self-confident, happier and more satisfied with their life; they better adapt to a new environment, achieve higher academic results, do not miss lessons without reasons and are more seldom expelled from school. The research results of Ciarrochi, Deane and Anderson (2002) revealed that emotional intelligence contributes to reduction of stress consequences, improves mental health and relieves depression; significant negative correlations were established among the sense of hopelessness, suicidal intentions and emotional intelligence.

Researchers have been further discussing the relationships among dimensions of individual's empathy (Crocetti et al., 2016) as well as development of expressiveness of empathy. It has been identified that boys' empathy is lower compared to that of girls (Carr \& Lutjemeier, 2005; Harrod \& Scheer, 2005; Eisenberg, Fabes, \& Spinrad, 2006; Karkauskaite, 2013). However, according to other authors, no differences in expression of certain aspects of empathy have been identified (Mestre, Frías, \& Samper, 2004; Garaigordobil, 2009). It can be assumed that empathy is one of the integral components of emotional intelligence and differences in its development as well as level of expression of components are likely to be predetermined by age, gender and other sociodemographic aspects. The majority of authors also envisage an obvious social benefit from development of emotional competence and emotional intelligence: according to Booth-Kewley and Friedman (1987) in future improving abilities of emotional intelligence are likely to lead to less aggressiveness and lower rates of violent crimes, fewer problems of mental health, reduced levels of morbidity and mortality due to traditional risk factors (smoking, drug abuse and other harmful addictions) resulting from lower emotional intelligence (Vandervoort, 2006; Kušlevič-Veršekienè \& Pukinskaitè, 2009). 
Generalising results of various research studies in the context of the analysed topic, the lack of research studies on the links of adolescents' emotional and social health with expression of various aspects of empathy can be seen. Therefore, the following question is formulated in this research: what relationships between dimensions of adolescents' social and emotional health and empathy are observed?

The research was conducted in nine schools of Lithuania (Vilnius, Anykščiai, Joniškis, Palanga, Šalčininkai, Šakiai and Švenčionys). The research sample included 546 adolescents: 284 boys (52\%) and 262 girls (48\%). Distribution of the participants according to age was as follows: $16.7 \%$ are 12 years old, $18.3 \%$ are 13 years old, $11 \%-14$ years old, $5.9 \%-15$ years old, $16.3 \%-16$ years old; $14.8 \%-17$ years old, $17 \%$ are 18 years old. The goal of the research: to carry out research on adolescents' social emotional health and its relationships with empathy. The objectives of the research: to identify a correlation between dispositions of social emotional health and empathy. The assumption formulated in the work: adolescents' social emotional health positively correlates with empathy.

\section{The methodologies of research}

Social Emotional Health Survey - Secondary (SEHS-S), Furlong et al. (2014). The questionnaire survey includes a wide range of social emotional psychological dispositions associated with positive development of young people. The constructive validity of this questionnaire was confirmed after the factor analysis of its invariance in groups formed on the base of sociocultural and gender principles (You et al., 2015). Permission to use the questionnaire was granted to A. Petrulytè. The double translation was done by $A$. Petrulytè and J. Bagdonavičiūtè.

The questionnaire consists of four dispositions/scales: Belief in self; Belief in others; Emotional competence; Engaged living. Each disposition embraces three unique sub-scales of mental health (12 in total). All the four dispositions make up a common indicator of social and emotional health. Every disposition/scale consists of three subscales. The first scale belief-in-self, consists: self-efficacy, self-awareness, and persistence. The second belief-in-others, consists: school support, peer support, and family support. The third emotional competence, consists: emotion regulation, empathy, and behavioural self-control. The final scale engaged living, consists: gratitude, zest, and optimism. The internal compatibility of Lithuanian version is sufficiently reliable and can be applied for evaluation of adolescents' social and emotional health (Cronbach alpha of the sub-scale of belief in self - 0.57 ; Cronbach alpha of the sub-scale of belief in others -0.41 ; Cronbach alpha of the subscale of emotional competence -0.61 ; Cronbach alpha of the sub-scale of engaged living - 0.70; Cronbach alpha of the common indicator of social and emotional health -0.78 ). The examples of items are as follows: "I can work out my problems", "I try to understand what other people go through", "Each day I look forward to having a lot of fun".

Interpersonal Reactivity Index (IRI), (Davis, 1980). The scale investigates various aspects of empathy and evaluates emotional reactions to negative experiences of other people. 
The scale consists of 28 items. The respondents were asked to rate every item on a 4-point scale (from 0 to 4) considering their suitability for characterisation of own attitude and feelings. The respondents evaluated statements while the supervisor was reading additional instructions. The scores of sub-scales were calculated summing up the evaluations of all the 7 items.

The scale of Interpersonal Reactivity Index (IRI) consists of 4 sub-scales that aim to evaluate different aspects of empathy:

I. Empathic concern scale. The sub-scale assesses emotional empathy, i.e. ability to feel compassion for others or tenderness to take care of them.

II. Perspective-taking scale. The sub-scale establishes the cognitive aspect of empathy, i.e. the ability to understand and adopt the attitude of other people.

III. Personal distress scale. The sub-scale evaluates the ability to experience distress and discomfort reacting to distress of others.

IV. Fantasy scale. The sub-scale evaluates the ability of respondents to transpose themselves imaginatively into the feelings. The sum of the sub-scales of perspective-taking and empathic concern makes up the index of empathy.

The author M. H. Davis granted the permission to use the Scale of Empathy to R. Pukinskaite and V. Guogienè. The scale of Interpersonal Reactivity Index was translated by R. Pukinskaite. The evaluation of internal compatibility of Lithuanian version showed sufficient reliability of sub-scales and their appropriateness for evaluation of adolescents' empathy (Cronbach alpha of the sub-scale of empathic concern - 0.51; Cronbach alpha of the sub-scale of perspective-taking -0.57 ; Cronbach alpha of personal distress -0.53 ; Cronbach alpha of fantasy - 0.56; Cronbach alpha of empathy index -0.69 ). The examples of items are as follows: "I really get involved with the feelings of the characters in a novel", "When I see someone being taken advantage of, I feel kind of protective towards the", "Sometimes I don't feel very sorry for other people when they are having problems".

The obtained data were processed using Microsoft Excel 2003, SPSS (Version 17 for Windows). The statistical analysis was applied. Establishing the link among the indicators of respondents' social and emotional health (SEHS-S) and empathy (IRI), the correlation analysis was applied and Spearman's rank correlation coefficient was calculated.

\section{The research results}

The following psychometric properties of scales of methodologies applied in the presented research according to the data on the respondents were identified: Cronbach alpha of the scale of SEHS-S - 0.78; that of IRI - 0.69. The total aggregate index of adolescents' SEHS-S is of four levels: low $-\leq 85$; low average $-86-106$; high average - 107-127 and high $-\geq 128$. The average score of SEHS-S of the adolescents in the research (12-18 years old) equals 109.3. The average of 109.5 was established in the group of 14-18 year old respondents in the researched carried out by M. Furlong in 2014, which almost complies with the data of the presented research. The data of this research (see: Figure 1) 
revealed that $4.9 \%$ of adolescents get to "low level" and are assigned to a "risk" group. The level of social and emotional health of about $11.1 \%$ of adolescents in the research is high, about half of respondents (46.8\%) fell within the high average level, whereas low average level was established in $33.7 \%$ of the adolescents (see: Figure 1).

Figure 1 Distribution of aggregate index of adolescents' social and emotional health (SEHS-S) according to levels of norms: low, low average, high average, high (in figures)

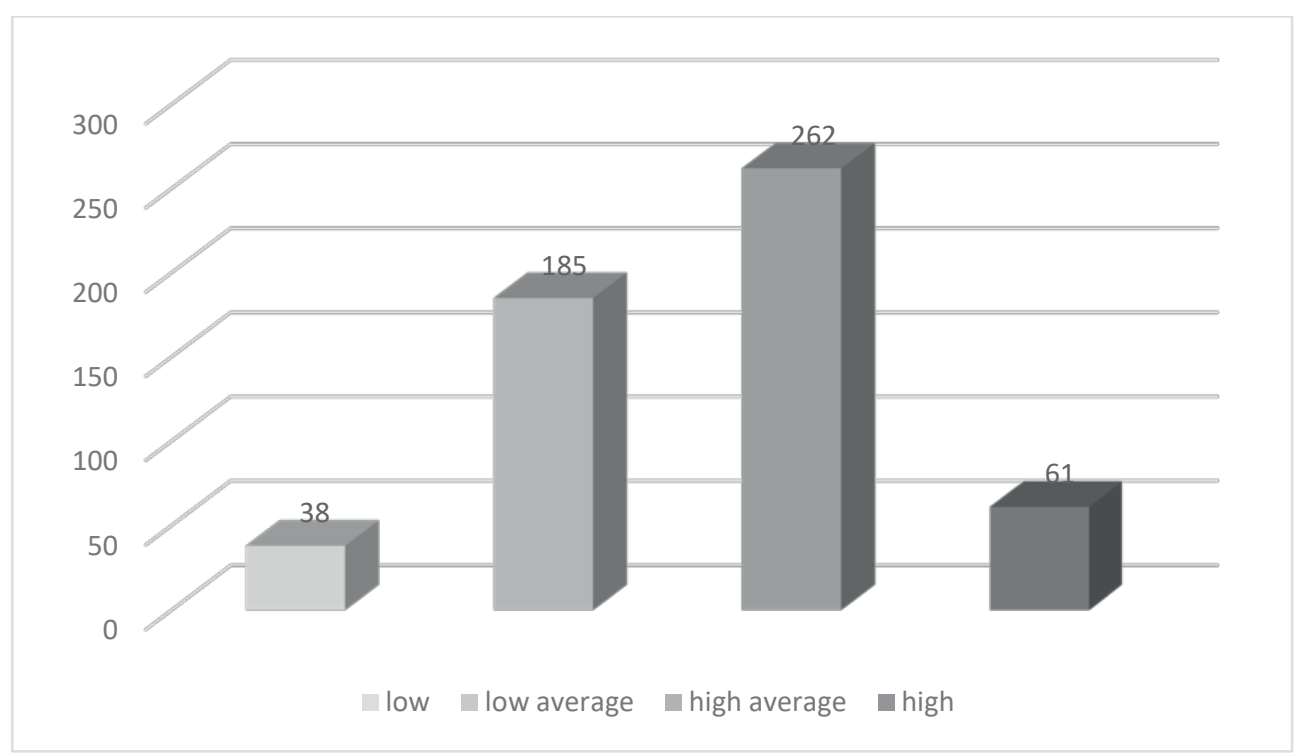

Conducting the research on adolescents' social and emotional health, it was important to analyse relationships of its different dimensions with empathy and psychometric characteristics of Social and Emotional Health Questionnaire (SEHS-S). The correlations identified in the scales of adolescents' social and emotional health (SEHS-S) and empathy (IRI) are presented further (see: Table 1). 
Table 1 The correlations of the scales of adolescents' emotional and social health (SEHS-S) with the indicators of empathy (IRI) (using Spearman's rank correlation coefficient p)

\begin{tabular}{|c|c|c|c|c|}
\hline SRI SEHS-S & Belief in self & Belief in others & $\begin{array}{c}\text { Emotional } \\
\text { competence }\end{array}$ & Engaged life \\
\hline Empathic concern & $0.31 * *$ & $0.32^{\star \star}$ & $0.48^{\star *}$ & $0.37^{* *}$ \\
\hline Perspective-taking & $0.16 * \star$ & $0.31 * \star$ & $0.45^{\star \star}$ & $0.36 * \star$ \\
\hline Fantasy & 0.04 & $0.11^{\star}$ & $0.35^{\star \star}$ & 0.07 \\
\hline Personal distress & $-0.34^{\star \star}$ & 0.05 & $-0.13 * \star$ & -0.04 \\
\hline
\end{tabular}

${ }^{* *} p \leq 0.000 ;{ }^{*} p \leq 0.05$

The correlation analysis allowed to reveal a positive significant correlation between the adolescents' emotional competence of the SEHS-S and the indicators of empathic concern $(r=0.48 ; p \leq 0.01)$, perspective-taking $(r=0.45 ; p \leq 0.01)$, fantasy $(r=0.35 ; p \leq$ 0.01 ) of the IRI scale and a very weak negative correlation with personal distress $(r=$ -0.13; $p \leq 0.01$ ). The indicator of belief in others in the SEHS-S questionnaire showed a weak significant positive correlation with the values of empathic concern $(r=0.32 ; p \leq$ $0.01)$, perspective-taking ( $r=0.31 ; p \leq 0.01)$ and fantasy $(r=0.11 ; p \leq 0.05)$ of the IRI scale. Engaged life in the SEHS-S scale significantly positively correlated with empathic concern ( $r=0.37 ; p \leq 0.01)$ and perspective-taking $(r=0.36 ; p \leq 0.01)$. Belief in self revealed a significant positive correlation with empathic concern $(r=0.31 ; p \leq 0.01)$ and perspective-taking $(r=0.16 ; p \leq 0.01)$ and a weakly negative correlation with the indicators of personal distress $(r=-0.34 ; p \leq 0.01)$. Generalising the investigated adolescents' dimensions, numerous positive relationships were identified and simultaneously the first assumption was confirmed that adolescents' social and emotional health is significantly positively related to the indicators of empathy: empathic concern, perspective-taking and fantasy. The obtained values of belief in self and emotional competence in the SEHS-S scale were negatively linked only to the indicators of personal distress of the empathy (IRI) scale.

Additional research focus was laid on how the items of the sub-scale of empathy of the adolescents' social and emotional health (SEHS-S) correlated with the sub-scale of empathic concern in the empathy (IRI) questionnaire. The conducted correlation analysis revealed relationships (see: Figure 2), which allowed to conclude that the sub-scale of adolescents' empathic concern (IRI) were significantly related to the following items of the sub-scale of empathy (SEHS-S): "I feel bad when someone gets his or her feelings hurt" $(r=0.57 ; p \leq 0.01)$; "I try to understand what other people go through" $(r=0.47$; $p \leq 0.01)$; "I try to understand how other people feel and think" ( $r=0.40 ; p \leq 0.01)$. 
Figure 2 The relationships between separate items of the sub-scale of empathy of adolescents' social and emotional health (SEHS-S) and the sub-scale of empathic concern in the empathy (IRI) scale (using Spearman's rank correlation coefficient p)

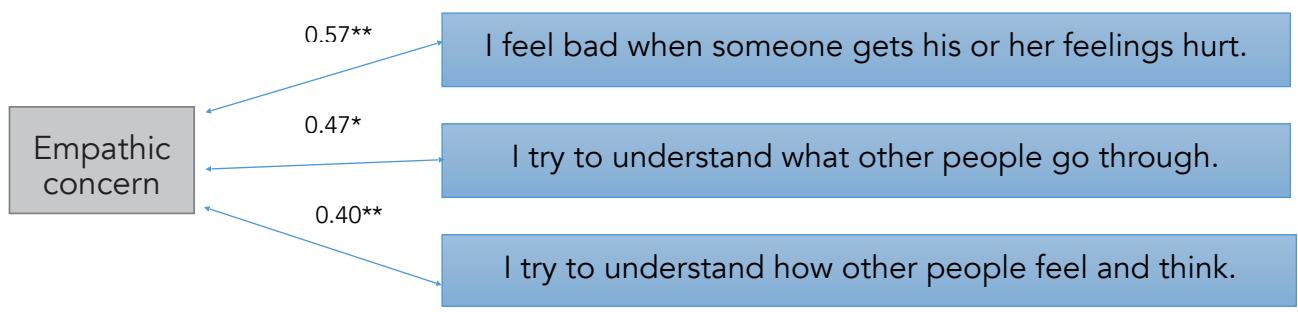

positive correlation

\section{Discussion}

The average of the sample of 12-18 year old adolescents in the research presented in this article is the same as that of white Americans in the research conducted by Furlong et al. (2014), which equals 109.5; i. e. falls within the level of "high average". About 5 per cent (4.9\%) of adolescents are attributed to "low" level and can face social and psychological problems. They should be provided with full attention and support. The level of health of about $11.1 \%$ adolescents is high and the majority of respondents fall within the levels of "high average" (46.8\%) and "low average" (33.7 \%). Comparing the results of the present research with those of previously conducted one (Petrulyte \& Guogiene, 2017), which embraced more than 1,600 school learners in Lithuania, a slight change was identified: the number of school learners assigned to the low level decreased by $3 \%$, a $4 \%$ fall in the number of school students with high level was established. The numbers of learners within "low average" and "high average" level rose respectively.

The research results revealed positive correlations of various dimensions of adolescents' social and emotional health. The established correlations of adolescents' dimensions confirmed the validity and reliability of the SEHS-S questionnaire. The moderate positive relationships between the adolescents' emotional competence in the SEHS-S questionnaire and two main aspects of empathy: empathic concern (emotional component of empathy) ( $r=0.48 ; p \leq 0.01$ ) and perspective-taking (cognitive component of empathy) $(r=0.45 ; p \leq 0.01)$ were obtained. Belief in others in the SEHS-S scale positively correlated with empathic concern $(r=0.32 ; p \leq 0.01)$ of IRI. The positive relationships were identified between engaged life (SEHS-S) and empathic concern ( $r=0.37 ; p \leq 0.01)$ as well as perspective-taking ( $r=0.36$; $p \leq 0.01)$ of IRI. Belief in self in the SEHS-S scale showed a positive correlation with empathic concern $(r=0.31 ; p \leq 0.01)$ and a negative correlation - with personal distress $(r=-0.34 ; p \leq 0.01)$. All the positive relationships revealed during the research do not contradict the research on expression of adolescents' 
emotional competence and emotional intelligence and social development conducted by other researchers (Mayer \& Forgas, 2001; Murphy et al., 2004; Petrides et al., 2006; Hoffman, 2000; Kradin, 2005; Carr \& Lutjemeier, 2005 and other) and are in line with the development of emotional competence and emotional intelligence. It is particularly important to conduct research on the adolescent emotional and social areas of health, which can be developed.

A weak negative correlation of SEHS-S with personal distress is in line with the results of the research conducted by Karkauskaite (2013), where a positive relationship of all forms of empathy with adolescent's prosocial behaviour (a desire to provide help in emergency or under request) was established with exception of personal distress. It would be interesting to carry out research on how adolescents' social and emotional health is related to other dimensions of personality, e.g., self-assessment and state of identity, behaviour characteristics and sociodemographic - cultural indicators. This could be focus for further research.

Discussing the limitations of the conducted research and its perspectives, the sample of the research could be expanded and the respondents could be investigated in terms age and gender. We want to note that the age norms for the use of the SEHS-S survey have not been specified in Lithuania yet. It would also be possible to take into consideration such indicators as the composition of the family, the socio-economic status of the family as well as the cultural and value-based aspects (Grusec, 2008; Chao \& Tseng, 2002; Kakihara \& Tilton-Weaver, 2009), the role of empathy in the moral development of an individual and in the context of parents' upbringing and relations with their children (Hoffman, 2000; Crocetti et al., 2016). For example, future research could focus on how parents' behaviour can elicit different effects for their children depending on the level of their empathy expressivity, how parents should communicate with children, who possess high level of empathy, and, therefore, are more vulnerable, etc.

It would be important to conduct research on how positive dispositions of adolescents are formed and how they relate to their successful adult life. Discussing the research perspectives, such factors as family composition, socio-economic status of family, cultural-value aspect, the role of empathy in the person's moral development and in the context of parents' upbringing and relations with children could be analysed.

\section{Conclusions}

The following correlations of the scales of adolescents' social and emotional health (SEHS-S) and empathy (IRI) were identified:

1. Emotional competence positively correlates with empathic concern $(r=0.48$; $p \leq 0.01)$, perspective-taking $(r=0.45 ; p \leq 0.01)$, fantasy $(r=0.35 ; p \leq 0.01)$;

2. Belief in others positively correlates with empathic concern $(r=0.32 ; p \leq$ $0.01)$, perspective-taking $(r=0.31 ; p \leq 0.01)$; engaged living is positively related to empathic concern ( $r=0.37 ; p \leq 0.01)$, perspective-taking $(r=0.36 ; p \leq 0.01)$;

3. Belief in self shows a positive correlation with empathic concern $(r=0.31 ; p \leq$ $0.01)$ and a negative correlation with personal distress $(r=-0.34 ; p \leq 0.01)$. 
Adolescents' strengths and "risk" factors could be evaluated by SEHS-S and, on the basis of this, psychological support of higher quality could be provided to adolescents, their parents, more targeted preventive activities could be implemented and favourable environment for education in the community seeking for psychological well-being could be created.

\section{References}

Baron, P., \& Richardson, D. (2001). Agressiya [Aggression]. Saint Petersburg: Piter.

Baron, R. (2000). Emotional and social intelligence: Insights from the Emotional Quotient Inventory (EQ-i). In R. Baron, \& J. D. A. Parker (Eds.), Handbook of emotional intelligence (pp. 363-388). San Francisco: Jossey-Bass.

Batson, C. D. (2009). These things called empathy: Eight related but distinct phenomena. In J. Decety, \& W. Ickes (Eds.), The Social Neuroscience of Empathy (pp. 3-15). Cambridge: MIT Press. doi: 10.7551/mitpress/9780262012973.003.0002

Booth-Kewley, S., \& Friedman, H. S. (1987). Psychological predictors of heart disease: A quantitative review. Psychological Bulletin, 101(3), 343-362.

Carr, M. B., \& Lutjemeier, J. A. (2005). The relation of facial affect recognition and empathy to delinquency in youth offenders. Adolescence, 40(159), 601-619.

Chao, R., \& Tseng, V. (2002). Parenting of Asians. In M. H. Bornstein (Ed.), Handbook of parenting: Social conditions and applied parenting (pp. 59-93). Mahwah: Erlbaum.

Ciarrochi, J. V., Chan, A. Y. C., \& Bajgar, J. (2001). Measuring emotional intelligence in adolescents. Personality and Individual Differences, 31(7), 1105-1119.

Ciarrochi, J. V., Deane, F. P., \& Anderson, S. (2002). Emotional intelligence moderates the relationship between stress and mental health. Personality and Individual Differences, 32(2), 197-209.

Cliffordson, C. (2002). The hierarchical structure of empathy: Dimensional organization and relations to social functioning. Scandinavian Journal of Psychology, 43(1), 49-59. doi: $10.1111 / 1467-9450.00268$

Cohen, D., \& Strayer, J. (1996). Empathy in conduct-disordered and comparison youth. Developmental Psychology, 32(6), 988-998. 
Crocetti, E., Van der Graaff, J., Moscatelli, S., Keijsers, L., Koot, H. M., Rubini, M., ... Branje, S. (2016). A longitudinal study on the effects of parental monitoring on adolescent antisocial behaviors: The moderating role of adolescent empathy. Frontiers in Psychology, 7. doi:10.3389/fpsyg.2016.01726

Davis, M. H. (1980). A multidimensional approach to individual differences in empathy. JSAS Catalog of Selected Documents in Psychology, 10, 85.

Davis, M. H. (1983). The effects of dispositional empathy on emotional reactions and helping: a multidimensional approach. Journal of Personality, 51(2), 167-184.

Decety, J., \& Cowell, J. M. (2014). The complex relation between morality and empathy. Trends in Cognitive Sciences, 18(7), 337-339.

Denham, S. (1998). Emotional development in young children. New York: Guilford Press.

Eisenberg, N., Fabes, R. A., \& Spinrad, T. L. (2006). Prosocial Development. In N. Eisenberg, W. Damon, \& R. M. Lerner (Eds.), Handbook of child psychology: Social, emotional, and personality development (pp. 646-718). New York: Wiley.

Furlong, M. J., You, S., Renshaw, T. L., Smith, D. C., \& O’Malley, M. D. (2014). Preliminary development and validation of the Social and Emotional Health Survey for secondary students. Social Indicators Research, 117(3), 1011-1032.

Furnham, A., \& Petrides, K. V. (2003). Emotional intelligence and happiness. Social Behaviour and Personality, 31(8), 815-824. doi: 10.2224/sbp.2003.31.8.815

Garaigordobil, M. (2009). A comparative analysis of empathy in childhood and adolescence: Gender differences and associated socio-emotional variables. International Journal of Psychology and Psychological Therapy, 9(2), 217-235.

Grusec, J. E. (2008). What is the nature of effective parenting? It depends. In M. Kerr, H. Stattin, \& R. C. M. E. Engels (Eds.), What Can Parents Do?: New Insights into the Role of Parents in Adolescent Problem Behavior (pp. 239-257). Chichester: John Wiley \& Sons. doi: $10.1002 / 9780470774113$

Harrod, N. R., \& Scheer, S. D. (2005). An exploration of adolescent emotional intelligence in relation to demographic characteristics. Adolescence, 40(159), 503-512.

Hoffman, M. L. (2000). Empathy and moral development: Implications for caring and justice. Cambridge: Cambridge University Press. doi: 10.1017/CBO9780511805851

Ignatavičienè, K. (2008). Iškritusių iš mokyklos mokinių grąžinimas. Vilnius: Kronta. 
Ivcevic, Z., Brackett, M. A., \& Mayer, J. D. (2007). Emotional Intelligence and Emotional Creativity. Journal of Personality, 75(2), 199-235.

Kakihara, F., \& Tilton-Weaver, L. (2009). Adolescents' interpretations of parental control: Differentiated by domain and types of control. Child Development, 80(6), 1722-1738.

Karkauskaitè, R. (2013). Paauglių vertybinių orientacijų, empatijos ir prosocialaus elgesio ypatumai bei tarpusavio ryšys (Magistro baigiamasis darbas, LSU, Kaunas, Lietuva). Retrieved from https://aleph.library.lt

Kradin, R. (2005). The roots of empathy and aggression in analysis. Journal of Analytical Psychology, 50(4), 431-449.

Kušlevič-Veršekienè, D., \& Pukinskaitè, R. (2009). Paauglių emocinis intelektas: psichosocialinių sunkumų, stresinių gyvenimo ivvykių bei demografinių charakteristikų analizè. Socialinis darbas, 8(1), 82-91.

Lee, S., You, S., \& Furlong, M. J. (2015). Validation of the Social Emotional Health Survey - Secondary for Korean Students. Child Indicators Research, 9(1), 73-92. doi:10.1007/ s12187-014-9294-y

Mayer, J. D., \& Forgas, P. (2001). Emotional intelligence in everyday life: scientific inquiry. Philadelphia: Psychology Press.

Mehrabian, A., \& Epstein, N. (1972). A measure of emotional empathy. Journal of Personality, 40(4), 525-543.

Mestre, V., Frías, D., \& Samper, P. (2004). La medida de la empatía: análisis del Interpersonal Reactivity Index. Psicothema, 16(2), 255-260.

Murphy, B. C., Shepard, S. A., Eisenberg, N., \& Fabes, R. A. (2004). Concurrent and across time prediction of young adolescents' social functioning: the role of emotionality and regulation. Social Development, 13(1), 56-86.

Newsome, S., Day, A. L., \& Catano, V. M. (2000). Assessing the predictive validity of emotional intelligence. Personality and Individual Differences, 29(6), 1005-1016.

O'Neil, J. (1996). On emotional intelligence: a conversation with Daniel Goleman. Educational Leadership, 54(1), 6-11.

Palmer, B., Donaldson, C., \& Stough, C. (2002). Emotional intelligence and life satisfaction. Personality and Individual Differences, 33(7), 1091-1100. 
Park, N., \& Peterson, Ch. (2008). Positive psychology and character strengths: application to strengths-based school counseling. Professional school counseling, 12(2), 85-92.

Petrides, K. V., Frederickson, N., \& Furnham, A. (2004). The Role of Trait Emotional Intelligence in Academic Performance and Deviant Behavior at School. Personality and Individual Differences, 36(2), 277-293.

Petrides, K. V., Frederickson, N., Sangareau, Y., \& Furnham, A. (2006). Trait emotional intelligence and children's peer relations at school. Social Development, 15(3), 537-547.

Petrulytė, A., \& Guogienè, V. (2017). Paauglių psichologinès sveikatos stiprinimas, vykdant tiriamąją ir prevencinę veiklą mokykloje. Pedagogika, 126(2), 99-114.

Pukinskaitè, R. (2006). Empatijos ir psichosocialinio funkcionavimo ypatybès paauglysteje. Socialinis darbas, 5(2), 55-62.

Pukinskaitè, R., \& Guogienè, V. (2010). Vyresniųjų paauglių pykčio ekspresijos ir kontrolès bei psichosocialinių sunkumų analizè. Visuomenès sveikata, 2(49), 104-113.

Qualter, P., \& Gardner, K. J. (2007). Emotional intelligence: review of research and educational implications. Pastoral Care in Education, 25(1), 11-20.

Reiff, H. B., Hatzes, N. M., Bramel, M. H., \& Gibbon, T. (2001). The relation of LD and gender with emotional intelligence in college students. Journal of Learning Disabilities, 34(1), 66-78.

Reynolds, W. J., \& Scott, B. (1999). Empathy: a crucial component of the helping relationship. Journal of Psychiatric and Mental Health Nursing, 6(5), 363-370.

Rubin, M. M. (1999). Emotional intelligence and its role in mitigating aggression: a correlational study of the relationship between emotional intelligence and aggression in urban adolescents. Unpublished manuscript, Immaculata College, Immaculata, PA.

Strayer, J., \& Roberts, W. (2004). Children's anger, emotional expressiveness, and empathy: relations with parents' empathy, emotional expressiveness, and parenting practices. Social development, 13(2), 229-254.

Suslavičius, A. (2000). Patariamoji psichologija kaip îtvirtinti savajji ego ir išlikti savimi. Kaunas: Šviesa.

Vandervoort, D. J. (2006). The importance of emotional intelligence in higher education. Current Psychology, 25(1), 4-7. 
Van der Graaff, J., Branje, S., De Wied, M., Hawk, S., Van Lier, P., \& Meeus, W. (2014). Perspective taking and empathic concern in adolescence: gender differences in developmental changes. Developmental psychology, 50(3), 881-888. Retrieved from https:// www.ncbi.nlm.nih.gov/pubmed/24040846

Van Noorden, T. H., Haselager, G. J., Cillessen, A. H., \& Bukowski, W. M. (2015). Empathy and involvement in bullying in children and adolescents: a systematic review. Journal of youth and adolescence, 44(3), 637-657. Retrieved from https://www.ncbi.nlm.nih.gov/ pubmed/24894581

Wells, J., Barlow, J., \& Stewart-Brown, S. (2003). A Systematic review of universal approaches to mental health promotion in schools. Health education, 103(4), 197-220.

White, S. J. (1997). Empathy: a literature review and concept analysis. Journal of Clinical Nursing, 6(4), 253-257.

Wied, M., Goudena, P. P., \& Matthys, W. (2005). Empathy in boys with disruptive behavior disorders. Journal of Child Psychology and Psychiatry, 46(8), 867-880.

You, S., Furlong, M., Felix, E., \& O'Malley, M. (2015).Validation of the social and emotional health survey for five sociocultural groups: multigroup invariance and latent mean analyses. Psychology in the schools, 52(4), 349-362.

\section{Authors}

Prof. Dr. Ala Petrulytè

Education Academy, Vytautas Magnus University

T. Ševčenkos g. 31, 03111 Vilnius, Lithuania

alapetrul@gmail.com

PsyM. Virginija Guogienè

Education Academy, Vytautas Magnus University

T. Ševčenkos g. 31, 03111 Vilnius, Lithuania

virginija.guogiene@gmail.com 